\title{
Temperature shifts and sporulation of Bacillus megaterium
}

\author{
Marie Strnadová, ${ }^{1}$ Michael Hecker, ${ }^{2}$ Lothar Wölfel, ${ }^{2}$ Hiltraud MaCH ${ }^{2}$ \\ and JiŘí CHALOUPKA ${ }^{1 *}$ \\ ${ }^{1}$ Institute of Microbiology, Department of Enzyme Engineering, Czechoslovak Academy of Sciences, Prague 4, \\ CS-14220, Czechoslovakia \\ ${ }^{2}$ Ernst-Moritz-Arndt University, Department of General Microbiology, Greifswald, O-2200 Germany
}

(Received 14 June 1990; revised 20 November 1990; accepted 4 December 1990)

\begin{abstract}
The permissive temperature for sporulation of Bacillus megaterium 27 (up to $42^{\circ} \mathrm{C}$ ) was found to be $4-5{ }^{\circ} \mathrm{C}$ lower than that for growth. The non-permissive temperature suppressed the initial phases of sporulation characterized by the synthesis of an extracellular proteinase but the cells retained the ability to sporulate for several hours. Neither growth at supraoptimal temperatures nor heat shock applied at the end of the growth phase increased the permissive sporulation temperature. The organism synthesized at least ten heat-shock proteins, the dominant one being HSP 69. These proteins were also found in cells after $3 \mathrm{~h}$ of incubation at $43.5{ }^{\circ} \mathrm{C}$ but their presence did not ensure the ability to sporulate at this temperature. The rise of temperature provoked an imbalance between synthesis and degradation of cellular proteins, whose role in suppression of sporulation is discussed.
\end{abstract}

\section{Introduction}

Temperature affects microbial cells both non-specifically, influencing the rates of biochemical reactions and, specifically, inducing or repressing enzyme synthesis (Chaloupka, 1985). An increased temperature brings about changes in membrane composition (Benschoter \& Ingram, 1986), inhibits septation (Fan, 1970), decreases the rate of ribosome synthesis (Zengel \& Lindahl, 1985) and stimulates protein catabolism (Pine, 1973). A further increase in temperature causes cell death. Cells can survive a temperature which otherwise kills them by having been exposed previously to a slightly supraoptimal temperature. This heat shock induces or enhances the synthesis of a set of proteins known as the heat-shock proteins (HSPs) (Schlesinger et al., 1982), which improve thermotolerance of the cell (Kusukawa \& Yura, 1988; Zhou et al., 1988). The ability to synthesize HSPs may be necessary for the growth of bacteria at higher temperatures (Yura et al., 1984). Spores of bacilli developed at higher temperature are more thermoresistant than those formed at a lower temperature (Khoury et al., 1987).

The formation of heat-shock proteins in bacilli can be induced during growth as well as during sporulation, the main ones being HSP 84-86, HSP 66-70, HSP 45, 32 and some of lower molecular mass (Streips \& Polio, 1985,

Abbreviation: HSP, heat-shock protein.
Todd et al., 1985). Some HSPs are present mainly in the membrane (HSP 87 and 66), while others are in the cytosol (Qoronfleh \& Streips, 1987).

Synthesis of some HSPs in bacilli may be induced not only by an increased temperature but also by other stresses including starvation (Richter \& Hecker, 1986). In other micro-organisms, both prokaryotic and eukaryotic, the synthesis of HSPs seems to be related to developmental stage or cytodifferentiation (Kurtz et al., 1986; Maniak \& Nellen, 1988; Killeen \& Nelson, 1988). Therefore, sporulation triggered by starvation could be accompanied by the synthesis of heat-shock proteins resulting in an increased thermotolerance. Contrary to this assumption, however, temperatures slightly higher than optimal yet permissive for growth were found not to be permissive for sporulation (Kučerová \& Chaloupka, 1985). An attempt to analyse this discrepancy is the subject of this communication.

\section{Methods}

Organism. Bacillus megaterium 27, which forms $70 \%$ sporangia during $7 \mathrm{~h}$ in sporulation media at $35^{\circ} \mathrm{C}$, was used throughout. The organism, the composition of the growth (SYG) and sporulation (SM) media, and the cultivation procedure were as described previously (Chaloupka et al., 1982). The medium SYG $-\mathrm{N}$ was derived from the 
growth medium SYG by omitting ammonia as nitrogen source. When growth was limited by nitrogen, the culture grown overnight in SYG $\left(\mathrm{OD}_{650} 1.0 ; 0.85 \mathrm{mg} \mathrm{dry} \mathrm{wt} \mathrm{ml}^{-1}\right)$ was diluted ninefold with SYG $-\mathrm{N}$ medium and grown further. The poor SG medium did not contain yeast extract.

Sporulation. This was initiated either by transfer of the culture at the end of the exponential phase to the sporulation medium SM or by growth in SYG - N to stationary phase. The development of sporangia was checked with a phase-contrast microscope (Amplival; Carl Zeiss). To quantify sporulation, at least 300 cells were counted in each sample. The number of heat-resistant spores was determined by plating a culture after heating for $10 \mathrm{~min}$ at $70^{\circ} \mathrm{C}$ on nutrient agar. In these experiments, $\mathrm{SM}$ or $\mathrm{SYG}-\mathrm{N}$ medium were supplemented with $0.1 \mathrm{mM}-\mathrm{CaCl}_{2}$.

Protein synthesis. This was estimated by incorporation of $\mathrm{L}-\left[{ }^{14} \mathrm{C}\right]-$

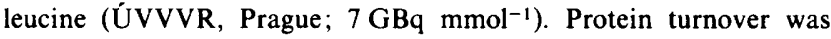
determined as described previously (Chaloupka \& Strnadová, 1982). The actual rate of protein degradation $\left(v_{\mathrm{a}}\right)$ was calculated according to the following formula:

$$
v_{\mathrm{a}}=\frac{f_{\mathrm{n}}-f_{\mathrm{n}+1}}{f_{\mathrm{n}}\left(t_{\mathrm{n}+1}-t_{\mathrm{n}}\right)} \times 100,
$$

where $f_{\mathrm{n}}$ and $f_{\mathrm{n}+1}$ are the fractions of radioactivity remaining in proteins at the time $t_{\mathrm{n}}$ and $t_{\mathrm{n}+1}$, respectively.

$P A G E$. Two-dimensional electrophoresis (PAGE) was performed according to O'Farrell (1975) in a cell-free extract of the cells labelled with ${ }^{35}$ S]methionine $\left(10 \mu \mathrm{ml}^{-1}, 54 \mathrm{TBq} \mathrm{mmol}{ }^{-1} ;\right.$ Amersham $)$ added $2 \mathrm{~min}$ after temperature equilibration. Incorporation proceeded for $10 \mathrm{~min}$ and was stopped by the addition of $0.15 \mathrm{mg}$ unlabelled methionine $\mathrm{ml}^{-1}$. The cells were disintegrated by sonication in the presence of $0.1 \mathrm{mg}$ chloramphenicol $\mathrm{ml}^{-1}$. The cell-free supernatants were lyophilized before analysis by PAGE. The fluorography was done according to Bonner \& Laskey (1974) using HS 11 ORWO film. The $10 \mu \mathrm{l}$ samples contained $30-40 \mu \mathrm{g}$ protein $\left(10^{6} \mathrm{c}\right.$.p.m. $)$. For the molecular mass calibration protein standards of $14,17 \cdot 8,25 \cdot 6,68$ and $90 \mathrm{kDa}$ were applied. Exposure time was $4 \mathrm{~d}$.

Determination of extracellular proteolytic activity. This was done with a radioactively-labelled protein substrate as described previously (Chaloupka et al., 1982).

\section{Results and Discussion}

The culture of Bacillus megaterium grew in the SYG medium and sporulated in the SM or SYG $-\mathrm{N}$ medium at almost the same optimum temperature $\left(40-42{ }^{\circ} \mathrm{C}\right.$ for growth, $40{ }^{\circ} \mathrm{C}$ for sporulation). However, the maximum temperatures for growth and sporulation differed. Whereas sporulation efficiency decreased substantially at $42{ }^{\circ} \mathrm{C}$ and was negligible at $43.5^{\circ} \mathrm{C}$ (Kučerová \& Chaloupka, 1985), the culture growth rate was only slightly decreased at the latter temperature - the value of $\mu$ was $1.22 \pm 0.08 \mathrm{~h}^{-1}$ as compared with $1.28 \pm 0.11 \mathrm{~h}^{-1}$ at $40{ }^{\circ} \mathrm{C}$ and $1.31 \pm 0.07 \mathrm{~h}^{-1}$ at $42^{\circ} \mathrm{C}$. The organism grew for at least $6 \mathrm{~h}$ at $45^{\circ} \mathrm{C}$ at $\mu=1.14 \pm 0.08 \mathrm{~h}^{-1}$ and only ceased to grow at temperatures higher than $47^{\circ} \mathrm{C}$.

Sporulation was triggered either by the transfer of the culture to the sporulation medium (SM) or by the exhaustion of ammonia in the SYG medium $(\mathrm{SYG}-\mathrm{N})$. Under both conditions, $60-80 \%$ of sporangia with refractile spores had developed after $7 \mathrm{~h}$ at $35^{\circ} \mathrm{C}$. When the culture grown in the SYG $-\mathrm{N}$ medium at $35^{\circ} \mathrm{C}$ was transferred to $43.5^{\circ} \mathrm{C}$ at the end of the exponential phase the sporulation efficiency at $7 \mathrm{~h}$ was decreased by $4-5$ orders of magnitude (Table 1). However, when the population incubated for $3-4 \mathrm{~h}$ in the sporulation medium (SM or SYG $-\mathrm{N}$ ) at $43.5^{\circ} \mathrm{C}$ or $45^{\circ} \mathrm{C}$ was transferred to $35^{\circ} \mathrm{C}$, the ability to sporulate was restored (Fig. 1 $a, b$ ). The length of the interval between the temperature down-shift and the appearance of sporangia indicated that sporulation was either substantially retarded (at $43.5^{\circ} \mathrm{C}$ ) or inhibited (at $45^{\circ} \mathrm{C}$ ). The early sporulation stages seem to be more sensitive to the increased temperature than the later ones, because the population incubated for $2-3 \mathrm{~h}$ at $43.5^{\circ} \mathrm{C}$ in $\mathrm{SM}$

\section{Table 1. Effect of heat shock on sporulation}

The cultures were grown in $S Y G-N$ medium and, at the beginning of the stationary phase, were transferred to the temperature indicated at which they were incubated for the next $7 \mathrm{~h}$.

\begin{tabular}{|c|c|c|c|c|}
\hline \multirow{2}{*}{$\begin{array}{l}\text { Growth } \\
\text { temperature } \\
\left({ }^{\circ} \mathrm{C}\right)\end{array}$} & \multirow{2}{*}{$\begin{array}{l}\text { Heat } \\
\text { shock* }\end{array}$} & \multirow{2}{*}{$\begin{array}{c}\text { Sporulation } \\
\text { temperature } \\
\left({ }^{\circ} \mathrm{C}\right)\end{array}$} & \multicolumn{2}{|r|}{ Sporulation $†$} \\
\hline & & & Sporangia $\ddagger$ & Heat-resistant spores $\S$ \\
\hline 35 & no & 35 & $68 \pm 11 \%(6)$ & $1.5 \times 10^{8}\left(2.9 \times 10^{7}-4.6 \times 10^{8}\right)(7)$ \\
\hline 35 & yes & 35 & $54 \pm 22 \%$ (4) & $2.9 \times 10^{8}\left(6.5 \times 10^{6}-7.6 \times 10^{8}\right)$ \\
\hline 35 & no & $43 \cdot 5$ & $0(4)$ & $5.1 \times 10^{3}\left(2.2 \times 10^{3}-8 \times 10^{3}\right)$ \\
\hline 35 & yes & $43 \cdot 5$ & $0(9)$ & $1.7 \times 10^{3}\left(3-6.1 \times 10^{3}\right)$ \\
\hline 42 & no & $43 \cdot 5$ & $0(2)$ & $2.0 \times 10^{3}\left(1.5 \times 10^{3}-2.5 \times 10^{3}\right)$ \\
\hline 45 & no & $43 \cdot 5$ & $0(2)$ & $76 \quad(31-120)$ \\
\hline
\end{tabular}

* $43.5^{\circ} \mathrm{C}$ for $40 \mathrm{~min}$ at the end of the growth phase.

$\dagger$ At $7 \mathrm{~h}$ of the stationary phase.

$\ddagger$ Determined by phase-contrast microscopy; 300 or more cells were evaluated and the percentage of sporangia was determined in each experiment. The number of experiments is indicated in parentheses

$\S$ Expressed as c.f.u. in $1 \mathrm{ml}$ per OD unit. The values in parentheses indicate the lowest and highest counts. The number of experiments is indicated on the right. 

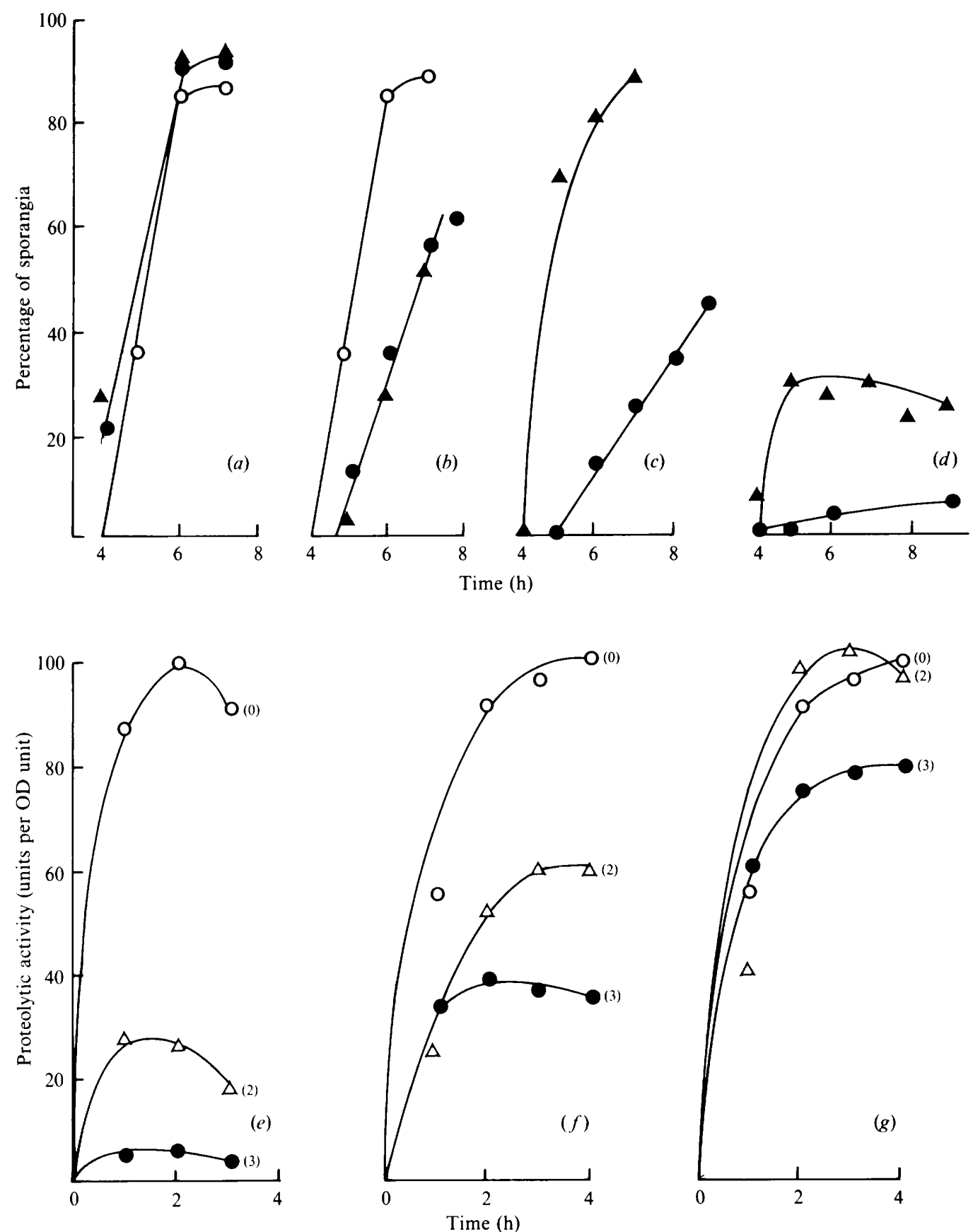

Fig. 1. Effect of temperature shifts on $(a-d)$ sporulation and $(e-g)$ proteinase synthesis. $(a, b)$ Temperature down-shift. The culture was incubated in SM for $3 \mathrm{~h}(\mathbf{O})$ or $4 \mathrm{~h}(\boldsymbol{\Delta})$ at $43.5^{\circ} \mathrm{C}(a)$ or $45^{\circ} \mathrm{C}(b)$ and then transferred to $35^{\circ} \mathrm{C}$. The control population $(\mathrm{O})$ was incubated at $35^{\circ} \mathrm{C}$ only. The percentage of sporangia developed during $4-7 \mathrm{~h}$ at $35^{\circ} \mathrm{C}$ is plotted against time. $(c, d)$ Temperature upshift. A culture incubated in SM at $35^{\circ} \mathrm{C}$ for $\left.3 \mathrm{~h}()^{\circ}\right)$ or $4 \mathrm{~h}(\boldsymbol{\Lambda})$ was transferred to $43.5^{\circ} \mathrm{C}(\mathrm{c})$ or $45^{\circ} \mathrm{C}(d)$. The percentage of sporangia is plotted against time of incubation at 43.5 or $45^{\circ} \mathrm{C}$. $(e, f, g)$. Effect of temperature down-shift on proteinase synthesis. The culture was incubated at $35(e), 43.5(f)$ or $45^{\circ} \mathrm{C}(g)$ in SM without $\mathrm{Ca}^{2+}$. It was then transferred to $35^{\circ} \mathrm{C}$ and supplemented with $1 \mathrm{mM}^{-} \mathrm{Ca}^{2+}$. Proteolytic activity in the supernatant is plotted against time at $35^{\circ} \mathrm{C}$. The time in hours of incubation in the absence of $\mathrm{Ca}^{2+}$ at the given temperature is shown for each curve.

developed more than $80 \%$ sporangia only after a further $6 \mathrm{~h}$ at $35^{\circ} \mathrm{C}$ and the culture incubated at $45^{\circ} \mathrm{C}$ sporulated even later. On the other hand, the cells transferred after $3 \mathrm{~h}$ at $35^{\circ} \mathrm{C}$ to a non-permissive temperature were capable of forming refractile spores without a substantial delay (Fig. 1c).

This conclusion was further substantiated by experiments in which the formation of an extracellular 

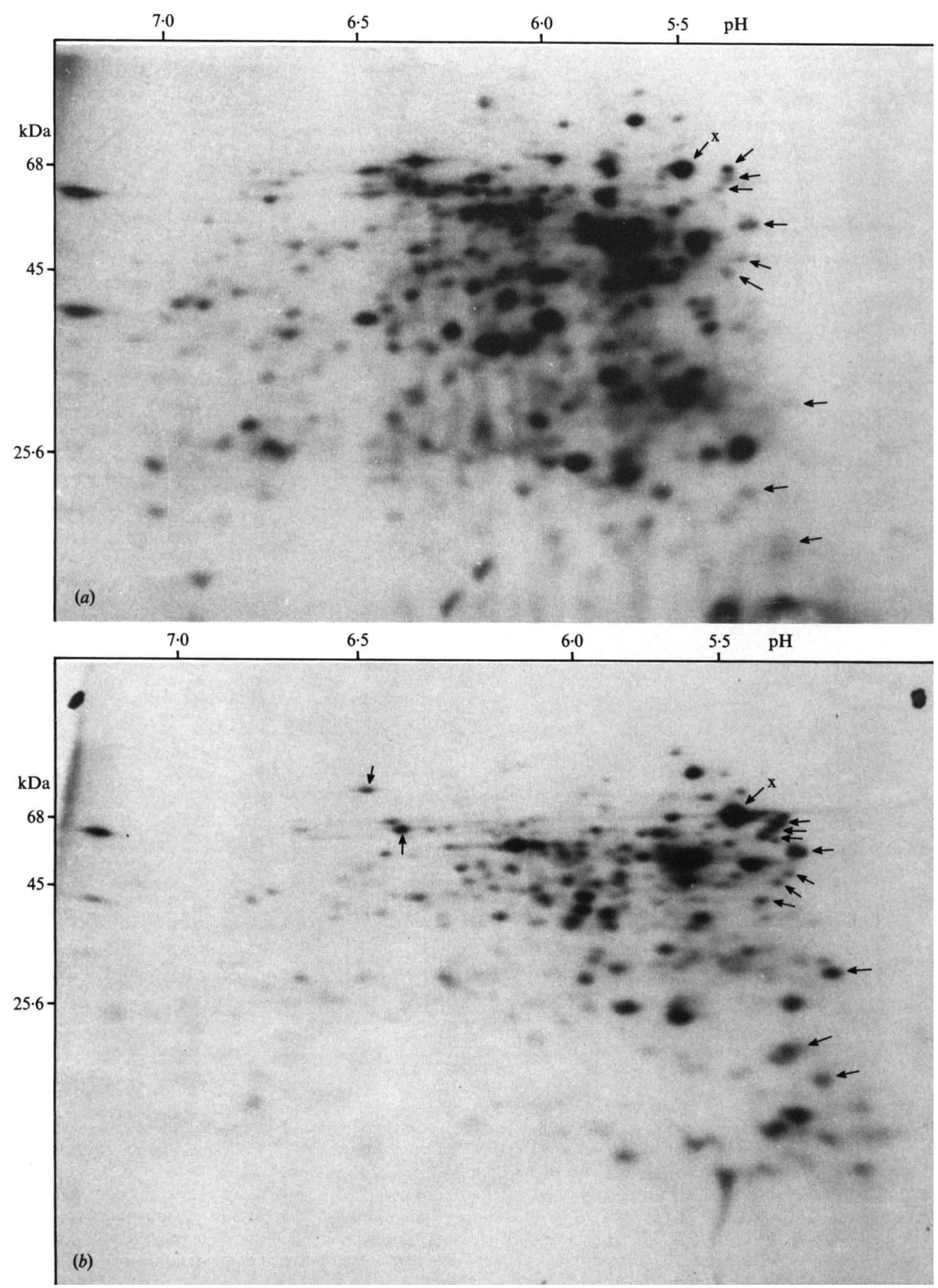

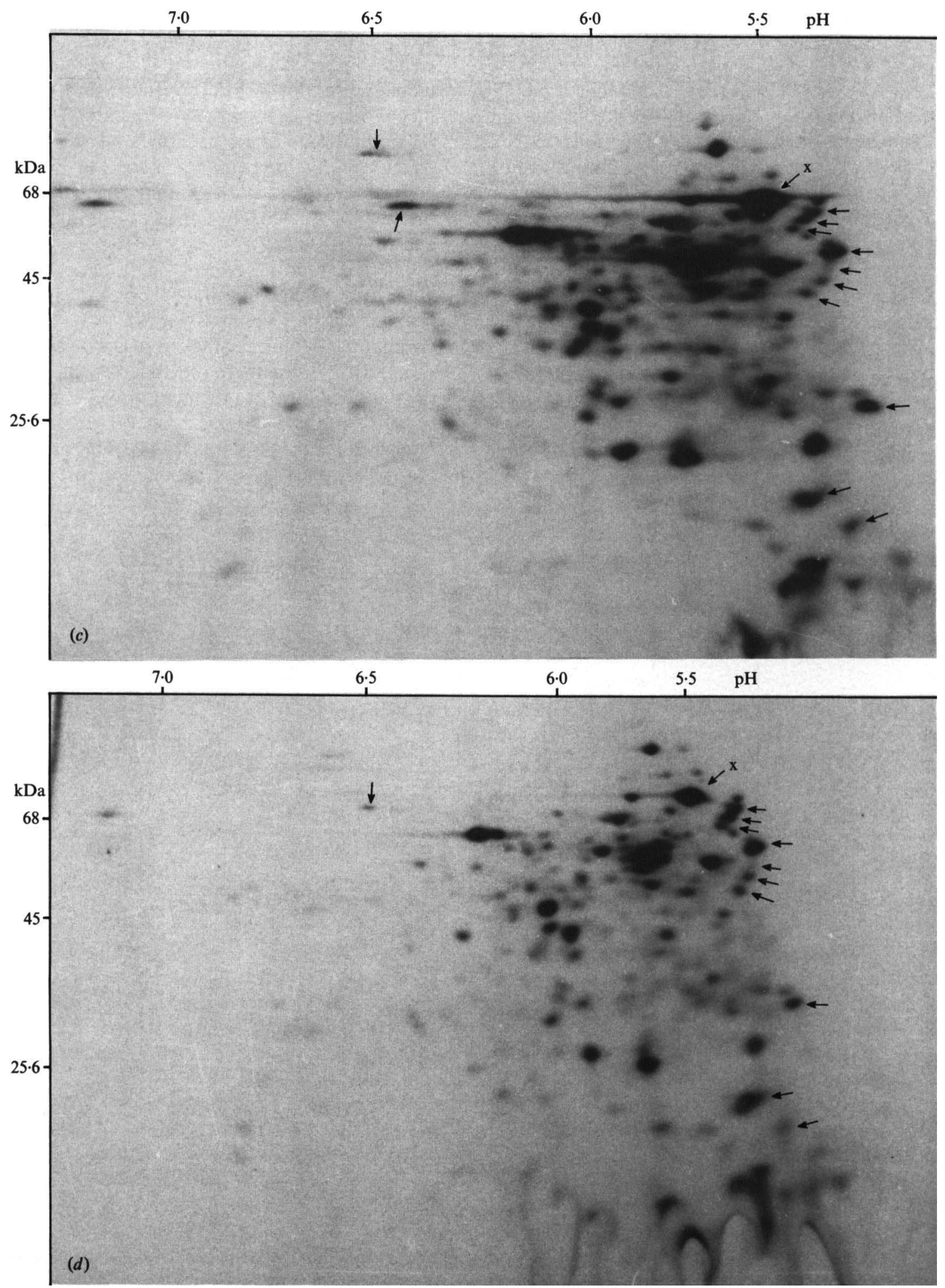

Fig. 2. Synthesis and degradation of HSP. PAGE of cell-free extracts prepared after labelling of postexponential cells with $\left[{ }^{35} \mathrm{~S}\right]$ methionine at $35^{\circ} \mathrm{C}(a), 43.5^{\circ} \mathrm{C}(b)$ and $45^{\circ} \mathrm{C}(d) .(a, b, d)$ Extracts prepared immediately; $(c)$ extract prepared after cells were incubated for $3 \mathrm{~h}$ at the stationary phase at $43.5^{\circ} \mathrm{C}$ in the presence of non-radioactive methionine. 
metalloproteinase was determined. As was shown previously, the ability to produce the proteinase was increased at the beginning of sporulation, reaching a maximum value after $1-1.5 \mathrm{~h}$ at $35^{\circ} \mathrm{C}$ and then it rapidly decreased (Chaloupka et al., 1982). The stability of the proteinase depends on the presence of $\mathrm{Ca}^{2+}$ ions. In their absence the newly synthesized enzyme is almost instantaneously inactivated (Ud Din et al., 1969). In order to find out whether the proteinase-forming ability would develop at an increased temperature the cultures were incubated in SM in the absence of $\mathrm{Ca}^{2+}$ at temperatures non-permissive for sporulation and $\mathrm{Ca}^{2+}$ was supplemented only when the population was transferred to $35^{\circ} \mathrm{C}$. When the culture was incubated at $35^{\circ} \mathrm{C}$ for the whole time period, almost no proteinase was produced when $\mathrm{Ca}^{2+}$ was supplemented after 2 or $3 \mathrm{~h}($ Fig. $1 e$ ). It can be speculated that the ability to form the proteinase was developed during first two or three hours but was not manifested because of the absence of $\mathrm{Ca}^{2+}$. However, when the culture was shifted from $43.5^{\circ} \mathrm{C}$ or $45^{\circ} \mathrm{C}$ to $35^{\circ} \mathrm{C}$, an increasing amount of the enzyme was synthesized. The amount of the enzyme formed after the temperature down-shift depended on the length of incubation at the increased temperature. It reached the maximum value when the population was incubated for $2 \mathrm{~h}$ at $45^{\circ} \mathrm{C}$ before being transferred to $35^{\circ} \mathrm{C}$. This is in accordance with the idea that the early sporulation phases were slowed down at $43.5^{\circ} \mathrm{C}$ or inhibited at $45^{\circ} \mathrm{C}$ and resumed at $35^{\circ} \mathrm{C}$.

The unfavourable effect of high temperatures on the viability of prokaryotic and eukaryotic cells can of ten be reduced by their previous exposure to a slightly supraoptimal temperature (Mackey \& Derrick, 1986; Carper et al., 1987). We therefore followed the effect of the previous exposure to a temperature of 42 or $45^{\circ} \mathrm{C}$ during growth on the subsequent sporulation at $43.5^{\circ} \mathrm{C}$, a temperature that was normally non-permissive. No thermotolerance of the sporulation process could be

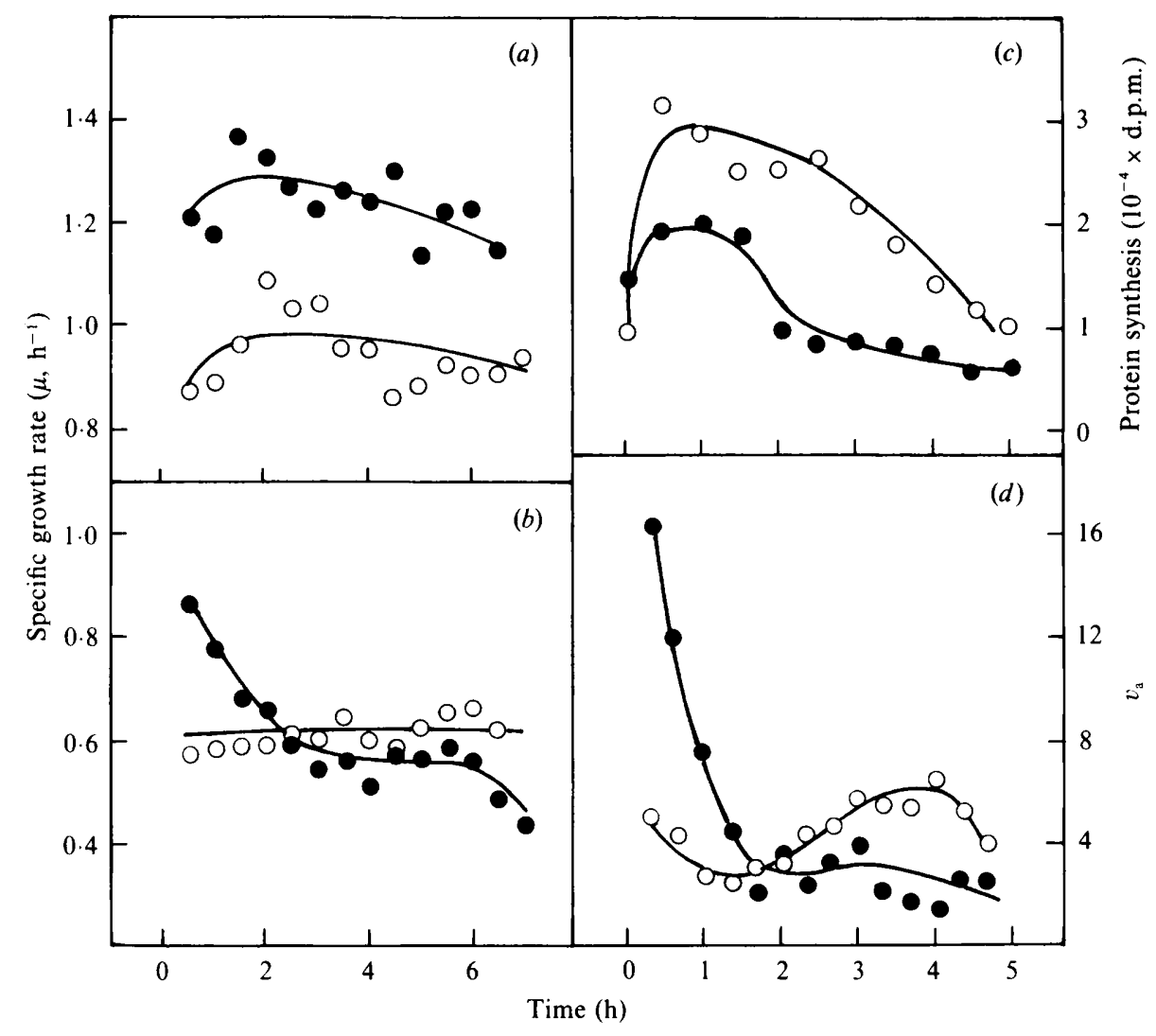

Fig. 3. Effect of temperature on specific growth rates and rates of protein synthesis and degradation. Growth at $(\mathrm{O}) 35^{\circ} \mathrm{C}$ and $(\odot)$ $43.5^{\circ} \mathrm{C}$. (a) Specific growth rate $\mu\left(\mathrm{h}^{-1}\right)$, calculated at $30 \mathrm{~min}$ intervals, in a complex medium (SYG), with the yeast extract increased to $0.5 \mathrm{mg} \mathrm{ml}^{-1}$. (b) Specific growth rates in SG medium. The cultures growing in SYG and SG medium were kept in the exponential phase by diluting with the fresh medium when an $\mathrm{OD}_{650}$ of 0.6-0.7 was reached. (c) Rates of protein synthesis in the sporulation medium SM determined by 20 min pulses of $\left[{ }^{14} \mathrm{C}\right]$ leucine. $(d)$ Actual rates of degradation of prelabelled proteins $\left(v_{\mathrm{a}}\right)$ in SM (in percentage per $40 \mathrm{~min}$ ) derived from the course of decrease of radioactivity in TCA-precipitable cell fraction. For details see Methods. 

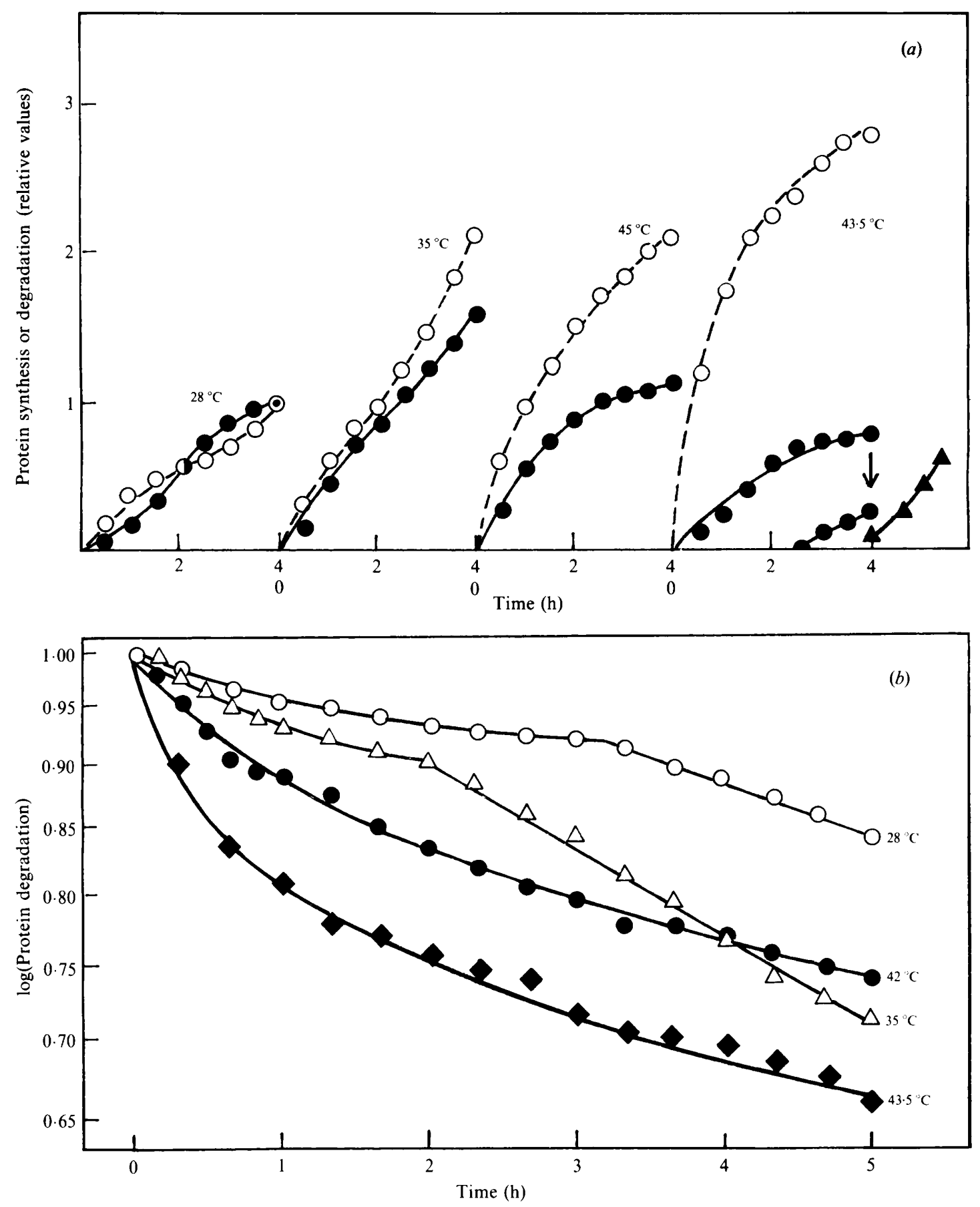

Fig. 4. Time course of protein synthesis and degradation in the sporulation medium. (a) Relative values of protein synthesis $(\boldsymbol{O})$ and degradation $(O)$ in SM at various temperatures. The radioactivity of $\left[{ }^{14} \mathrm{C}\right]$ leucine incorporated after $4 \mathrm{~h}$ at $28^{\circ} \mathrm{C}$ was set to 1.00 ; its mean value corresponded to 9700 d.p.m. (mgdry mass) ${ }^{-1} ;$ at $43.5^{\circ} \mathrm{C}\left[{ }^{14} \mathrm{C}\right]$ leucine was also added after $2.5 \mathrm{~h} . \mathbf{\Delta},\left[{ }^{14} \mathrm{C}\right]$ Leucine was added at $4 \mathrm{~h}$ after dilution with the fresh SG. The portion of prelabelled proteins (labelling time $1 \mathrm{~h}$ ) degraded after $4 \mathrm{~h}$ at $28^{\circ} \mathrm{C}$ was set to 1.00 . This value corresponded to $11 \%$ of radioactivity present in the cell proteins at zero time. (b) Semilogarithmic plot of the time course of protein degradation. Radioactivity of proteins at zero time was set to 1.00 . 
found by this treatment (Table 1). Also, a combination of the temperature shifts up and down $\left(35 \rightarrow 43.5 \rightarrow 35^{\circ} \mathrm{C}\right)$ during growth had no positive effect on the sporulation at the non-permissive temperature. Moreover, growth at a higher temperature resulted in a delay of sporulation at the permissive temperature. The percentages of sporangia developed after $7 \mathrm{~h}$ at $35^{\circ} \mathrm{C}$ in populations pregrown at $42^{\circ} \mathrm{C}$ and $45^{\circ} \mathrm{C}$ were 36 and $8 \%$ respectively (as determined by phase-contrast microscopy). The numbers of heat-resistant spores in $1 \mathrm{ml}$ per unit of optical density were $1.9 \times 10^{7}$ and $8.9 \times 10^{6}$ for cells pregrown at $42{ }^{\circ} \mathrm{C}$ and $45^{\circ} \mathrm{C}$, respectively. However, the normal number of spores was found after $24 \mathrm{~h}$.

These results may suggest that either the formation of heat-shock proteins, which could increase thermotolerance during sporulation, was impaired in B. megaterium, or that these HSPs might be rapidly degraded, as was found in eukaryotes (Dabrowa \& Howard 1984; Rechsteiner et al., 1987). The organism synthesized at least ten HSPs when treated at temperatures of 43.5 or $45^{\circ} \mathrm{C}$ during the postexponential phase (Fig. $2 a, b, d$ ). HSP 69 , marked as $\mathrm{x}$ in the autoradiogram (Fig. 2), was the most prominent. This HISP seems to be the most important for the induction of thermotolerance in many organisms (Schlesinger, 1986). The molecular masses of other HSPs were $80,62,60,68,55,44-49,30,23$ and $21.5 \mathrm{kDa}$. HSP 69 was present in cells grown at $35^{\circ} \mathrm{C}$ but its level substantially increased after a heat shock and it was also synthesized at $48{ }^{\circ} \mathrm{C}$, when most of the cellular proteins ceased to be formed (data not shown). Unlike HSP 70 in eukaryotic cells, this protein, like other HSPs in $B$. megaterium, was not degraded to a greater extent during $3 \mathrm{~h}$ of incubation at $43.5^{\circ} \mathrm{C}$ (Fig. $2 c$ ). It thus seems probable that neither the inefficient synthesis of cytosol HSPs nor their rapid degradation could be responsible for a low thermotolerance of sporulation.

The possible reasons for a high sensitivity of sporulation towards an increased temperature are numerous. One of the factors involved could be the inhibition of septation, since several bacilli including $B$. megaterium grow at high temperatures in the form of non-septate filaments (Chaloupka et al., 1974). The increased temperature also suppresses the synthesis of the main $\sigma^{43}$ and a minor sigma subunit, $\sigma^{28}$, of RNA polymerase (Arnosti et al., 1986). The eventual role of the latter in transcription of sporulation operons is, however, not clear. The other factor that probably plays a role in suppression of sporulation is the imbalance between protein degradation and synthesis. It is known that increased temperature stimulates intracellular protein catabolism in E. coli and that the lon proteinase belongs to the heat-shock proteins (Chung \& Goldberg, 1981). Also, in $B$. megaterium at temperatures exceeding the growth optimum, the portion of protein degraded increases for each population doubling. This is obvious during growth in poor media (Strnadová et al., 1986). A lower protein catabolism in rich media seems to result in a shift of the $T_{\max }$ towards the higher temperature, as was shown by comparing the specific growth rates at 43.5 and $35^{\circ} \mathrm{C}$ (Fig. $3 a, b$ ). Although, in the complex medium SYG, values for $\mu$ at $43.5^{\circ} \mathrm{C}$ remained substantially higher for many generations than those at $35^{\circ} \mathrm{C}$, in the simple medium SG, values of $\mu$ at $43.5^{\circ} \mathrm{C}$ decreased to a value which was slightly lower than that at $35^{\circ} \mathrm{C}$ $\left(0.56 \pm 0.03 \mathrm{~h}^{-1}\right.$ at $43.5^{\circ} \mathrm{C}$ as compared with $0.62 \pm 0.03 \mathrm{~h}^{-1}$ at $35^{\circ} \mathrm{C}$ ). In the sporulation medium, the optimum temperature for protein synthesis was lower than that for growth in a poor medium. However, the actual rates of degradation of prelabelled proteins at the beginning of sporulation were higher at $43.5^{\circ} \mathrm{C}$ than those at $35^{\circ} \mathrm{C}$. Later, the degradation rate at $35^{\circ} \mathrm{C}$ increased in connection with the development of a more efficient proteolytic system, whose formation was suppressed at $43.5^{\circ} \mathrm{C}$ (Figs $3 d$ and $4 b$ ).

The relative ratio of protein synthesis to protein degradation at different temperatures is shown in Fig. 4(a). It is evident that the increasing temperature brought about a disparity between the synthesis and degradation of proteins. However, the population incubated for $4 \mathrm{~h}$ at $43.5^{\circ} \mathrm{C}$ was capable of increasing protein synthesis immediately after dilution with fresh SG growth medium. This indicates that the cells remained capable of restoring their physiological activity immediately. The kinetics of protein degradation is shown in Fig. 4(b). The initial rate of protein catabolism increased with rising temperature but the development of an efficient proteolytic system in later sporulation phases was suppressed at temperatures higher than $35^{\circ} \mathrm{C}$ (compare the kinetics at 35 and 42 or $43.5^{\circ} \mathrm{C}$ ). It would be difficult to argue that the imbalance between protein synthesis and degradation is a crucial factor involved in the suppression of sporulation by an increased temperature. Undoubtedly, however, it plays an important role in the pleiotropic effect of temperature on this type of prokaryotic cytodifferentiation.

\section{References}

Arnosti, D. N., Singer, V. L. \& Chamberlin, M. J. (1986). Characterization of heat shock in Bacillus subtilis. Journal of Bacteriology 168, 1243-1249.

BenSCHOTER, A. S. \& INGRAM, L. O. (1986). Thermal tolerance of Zymomonas mobilis: temperature-induced changes in membrane composition. Applied and Environmental Microbiology 51, 1278-1284.

BonNer, W. M. \& LASKey, R. A. (1974). A film detection method for tritium-labelled proteins and nucleic acids in polyacrylamide gels. European Journal of Biochemistry 46, 83-88.

Carper, S. W., Duffy, J. J. \& Gerner, E. W. (1987). Heat shock proteins in thermotolerance and other cellular processes. Cancer Research 47, 5249-5255. 
ChaloupKa, J. (1985). Temperature as a factor regulating the synthesis of microbial enzymes. Microbiological Sciences 2, 86-90.

ChaloupKa, J. \& Strnadová, M. (1982). Kinetics of protein turnover in growing cells of Bacillus megaterium. Journal of General Microbiology 128, 1003-1008.

Chaloupka, J., KŘkěKová, P., Čáslavská, J. \& Strnadová, M. (1974). Turnover of murein in cellular and filamentous populations of Bacillus megaterium. Folia Microbiologica 19, 257-263.

Chaloupka, J., Severin, A. I., Kučerová, H. \& Strnadová, M. (1982). Differences in the regulation of exocellular proteinase synthesis during growth and sporogenesis of Bacillus megaterium. Canadian Journal of Microbiology 28, 1214-1218.

ChUnG, C. H. \& GoldberG, A. L. (1981). The product of the lon (capR) gene in Escherichia coli is the ATP-dependent protease: protease La. Proceedings of the National Academy of Sciences of the United States of America 78, 4931-4935.

DaBrowa, N. \& Howard, D. H. (1984). Heat shock and heat stroke proteins observed during germination of the blastoconidia of Candida albicans. Infection and Immunity 44, 537-539.

FAN, D. P. (1970). Autolysin(s) of Bacillus subtilis as dechaining enzyme. Journal of Bacteriology 103, 494-499.

Khoury, P. H., Lombardi, S. J. \& SLePECKy, R. (1987). Perturbation of heat resistance to bacterial spores by sporulation temperature and ethanol. Current Microbiology 15, 15-19.

KILLEEN, K. P. \& Nelson, D. R. (1988). Acceleration of starvation and glycerol-induced myxospore formation by prior heat shock in Myxococcus xanthus. Journal of Bacteriology 170, 5200-5207.

KuČEROVÁ, H. \& CHALOUPKA, J. (1985). Suppression by temperature of sporulation and of extracellular metalloproteinase synthesis in Bacillus megaterium. FEMS Microbiology Letters 28, 293-296.

KuRTZ, S., Rossi, J. , PetKo, L. \& LindQuist, S. (1986). An ancient developmental induction: heat-shock proteins induced in sporulation and oogenesis. Science 231, 1154-1157.

Kusukawa, N. \& Yura, T. (1988). Heat shock protein, GroE, of Escherichia coli: key protective roles against thermal stress. Genes and Development 2, 874-882.

MACKeY, B. M. \& DerRicK, C. M. (1986). Elevation of the heat resistance of Salmonella typhimurium by sublethal heat shock. Journal of Applied Bacteriology 61, 389-393.

MANIAK, M. \& NELLEN, W. (1988). A developmentally regulated membrane protein gene in Dictyostelium discoideum is also induced by heat shock and cold shock. Molecular and Cellular Biology 8, 153159.
O'FARrell, P. H. (1975). High resolution two-dimensional electrophoresis of proteins. Journal of Biological Chemistry 250, 4007-4021.

PINE, M. J. (1973). Regulation of intracellular proteolysis in Escherichia coli. Journal of Bacteriology 115, 107-116.

QORONFLEH, M. W. \& STREIPS, U. N. (1987). Initial subcellular localization of heat-shock proteins in Bacillus subtilis. FEMS Microbiology Letters 43, 373-377.

RechSteiner, M., Rogers, S. \& Rote, K. (1987). Protein structure and intracellular stability. Trends in Biochemical Sciences 12, 390-394.

RICHTER, A. \& HECKER, M. (1986). Heat-shock proteins in Bacillus subtilis: a two-dimensional gel electrophoresis study. FEMS Microbiology Letters 36, 69-71.

SCHLESINGER, M. J. (1986). Heat shock proteins: the search for functions. Journal of Cell Biology 103, 321-325.

Schlesinger, M. J., Ashburner, M. \& Tissieres, A. (eds) (1982). Heat-shock - From Bacteria to Man. Cold Spring Harbor, NY : Cold Spring Harbor Laboratory.

Streips, U. N. \& Polio, F. W. (1985). Heat shock proteins in bacilli. Journal of Bacteriology 162, 434-437.

Strnadová, M., Prasad, R., Kučerová, H. \& Chaloupka, J. (1986) Effect of temperature on growth and protein turnover in Bacillus megaterium. Journal of Basic Microbiology 26, 289-298.

Todd, J. A., Hubbard, T. J. P., Travers, A. A. \& Ellar, D. J. (1985) Heat shock proteins during growth and sporulation of Bacillus subtilis. FEBS Letters 188, 209-214.

UD DIN, F., Ǩ̌EČKovÁ, P. \& CHALOUPKA, J. (1969). Regulation of the formation of protease in Bacillus megaterium. III. Enzyme production under limitation by nitrogen source. Folia Microbiologica 14, 70 76.

YURA, T., TOBE, T., ITO, K.\& OSAWA, T. (1984). Heat shock regulatory gene $(h t p R)$ of Escherichia coli is required for growth at high temperature but is dispensable at low temperature. Proceedings of the National Academy of Sciences of the United States of America 81, 6804-6807.

ZENGEL, J. M. \& LINDAHL, L. (1985). Transcriptional control of the S10 ribosomal protein operon of Escherichia coli after a shift to higher temperature. Journal of Bacteriology 163, 140-147.

Zhou, Y.-N., Kusukawa, N., Erickson, J. W., Gross, C. A. \& Yura, T. (1988). Isolation and characterization of Escherichia coli mutants that lack the heat shock sigma factor $\sigma^{32}$. Journal of Bacteriology 170, 3640-3649. 